\title{
ELIMINASI GANGGUAN MATRIKS DALAM ANALISIS MERKURI HG SEBAGAI SENYAWA KOMPLEKS THIO MICHLER'S KETON SECARA SPEKTROFOTOMETRI
}

\author{
Sukib, Muti'ah \\ Program Studi Pendidikan Kimia, FKIP Universitas Mataram, Jl. Majapahit No. 62 Mataram \\ Email: sukib.fkip@unram.ac.id
}

\begin{abstract}
Abstrak. Telah dilakukan penelitian tentang penyusunan metode analisis merkuri melalui pembentukan senyawa kompleks dengan 4,4'-Bis(dimethylamino)thio-benzophenone TMK. Senyawa kompleks tersebut berwarna biru kehijauan yang dapat dideteksi dengan spektrofoto-meter pada kondisi: $\lambda$ max $574 \mathrm{~nm}$; $\mathrm{pH} 3$; konsentrasi TMK 0,0002 M, dan waktu tunggu selama 4-10 menit. perbandingan volume pereaksi: $\mathrm{Hg}(\mathrm{II})$, bufer $\mathrm{pH} \mathrm{3,} \mathrm{TMK} \mathrm{0,002}$ $\mathrm{M}, \mathrm{H}_{2} \mathrm{O}$ bebas ion adalah 1:1:1:7. Dari hasil penelitian menunjukkan bahwa metode ini telah memenuhi validitas, yaitu: linieritas $0,05-2,0 \mathrm{mg} / \mathrm{L}$, limit deteksi $0,008 \mathrm{mg} / \mathrm{L}$, dan $\%$ recovery antara $98 \%-102 \%$. Gangguan matriks akibat adanya ion-ion $\mathrm{Au}(\mathrm{III}), \mathrm{Ag}(\mathrm{I}), \mathrm{Pd}(\mathrm{II}), \mathrm{Cu}(\mathrm{II}), \mathrm{Co}(\mathrm{II})$, dan $\mathrm{Fe}(\mathrm{II})$ dapat dieliminasi dengan metode ekstraksi pelarut dan adisi standar. Metode adisi standar terbukti mampu memberikan data hasil pengukuran yang dapat dipercaya pada $\alpha 5 \%$, yaitu untuk sampel buatan sebesar $(0,053 \pm 0,001) \mathrm{mg} / \mathrm{L}$, air sungai $(0,034 \pm 0,004) \mathrm{mg} / \mathrm{L}$, dan sedimen sebesar $(4,172 \pm 0,050) \mathrm{mg} / \mathrm{kg}$. Dari hasil penelitian ini dapat disimpulkan bahwa metode ekstraksi pelarut dan adisi standar mampu mengeliminasi gangguan matriks pada analisis merkuri sebagai kompleks $\mathrm{Hg}$ TMK secara spektrofotometri
\end{abstract}

Kata kunci: Metode analisis merkuri, Thio Michler's keton, eliminasi, gangguan matriks

Abstract. A research of analysis method for determination of mercury through formation of complex with 4,4'bis(dimethylamino)thiobenzophenone TMK has been conducted. The green blue complex compound can be detected with spectrophoto-meter in conditions: $\lambda \max 574 \mathrm{~nm}$, buffer acetate $\mathrm{pH} 3$, concentration of TMK 0,0002 $\mathrm{M}$, and the absorbance of complex remains stable for 4-10 minutes. The formula of reagents volume for: $\mathrm{Hg}$ (II): buffer acetate $\mathrm{pH}$ 3: TMK $0,002 \mathrm{M}$ : de-ionized water is $1: 1: 1: 7$. This method is valid, with parameters such as linearity $0.05-2.00 \mathrm{mg} / \mathrm{L}$, limit of detection $0.008 \mathrm{mg} / \mathrm{L}$, and recovery in the range $98 \%-102 \%$. Matrix interferences that are caused by $\mathrm{Au}(\mathrm{III}), \mathrm{Ag}(\mathrm{I}), \mathrm{Pd}(\mathrm{II}), \mathrm{Cu}(\mathrm{II}), \mathrm{Co}(\mathrm{II})$, and $\mathrm{Fe}(\mathrm{III})$ ions can be eliminated with solvent extraction and standard addition methods. Standard addition method is able to give data of trusty measurement result at $\alpha 5 \%$, that is for synthesis sample as $(0.053 \pm 0.001) \mathrm{mg} / \mathrm{L}$, river water $(0.034 \pm 0.004) \mathrm{mg} / \mathrm{L}$, and for sediment $(4.172 \pm$ $0.050) \mathrm{mg} / \mathrm{kg}$. From the result of this research, it can be concluded that solvent extraction and standard addition methods are able to eliminated matrix interferences in mercury analysis as Hg-TMK complex spectrophotometrically

Key waords: mercury analysis method, Thio Michler's ketone, elimination, matrix interferences

\section{PENDAHULUAN}

Deteksi merkuri dalam sampel air, sedimen, biota (ikan, udang, kerang), dan hasil pertanian (sayuran, buah-buahan) sangat diperlukan, sehingga keamanan pangan dan lingkungan dapat terjamin [1],[2]. Hal ini terkait dengan sifat toksik merkuri pada manusia yang dapat menyebabkan bronkitis akut, kerusakan ginjal, kerja enzim, badan gemetar, kaki terasa mati, hiposensitif, kebingungan, murung, depresi, koma, dan akhirnya kematian [3],[4]. Efek pada ibu hamil dapat menyebabkan keguguran janin, dan cacat mental maupun fisik [5]

Nilai ambang batas merkuri dalam bahan pangan sangat rendah, misalnya dalam air minum $0,006 \mathrm{mg} / \mathrm{L}$ dan dalam ikan 0,6 mg/kg [4], oleh sebab itu diperlukan metode analisis khusus. Metode yang digunakan adalah CV-AAS, ICP-AES, ICP-MS, namun memerlukan peralatan mahal, biaya perawatan tinggi dan keahlian khusus [6]. Oleh sebab itu sulit terjangkau oleh laboratorium di negara berkembang apalagi laboratorium di daerah.

Analisis merkuri dengan metode spektrofotometri membutuhkan biaya peralatan relatif murah dan cara kerjanya sederhana, tetapi membutuhkan proses reaksi kimia spesifik. Reaksi antara ion $\mathrm{Hg}^{2+}$ dengan thio Michler's ketone $\left(4,4^{\prime}\right.$ Bis(dimethylamino) thio-benzophenone) pertamakali ditemukan pada tahun 1949 oleh Gehauf dan Goldenson [7]. Hal tersebut menjadi dasar dalam penyusunan metode analisis merkuri sebagaimana dilaporkan oleh Niazi dan tim penelitinya [8]. Dalam penelitian tersebut Niazi dan timnya menerapkan teknik cloud point extraction dengan menggunakan surfaktan Triton X-114.

Analisis logam yang didasarkan pada pembentukan senyawa kompleks pada umumnya sulit 
larut dalam air, namun hasil penelitian yang dilakukan oleh Sukib dan Loka menunjukkan bahwa senyawa kompleks ion merkuri $\mathrm{Hg}^{2+}$ dengan thio Michler's keton TMK memiliki sifat larut dalam air [9]. Oleh sebab itu senyawa kompleks hasil reaksi dapat dideteksi langsung dengan alat spektrofotometer, sehingga memerlukan waktu yang lebih singkat. Kendala yang ditemukan adalah adanya ion logam lain yang membentuk kompleks dengan TMK, terutama: $\mathrm{Ag}^{+}, \mathrm{Cu}^{2+}, \mathrm{Pd}^{2+}, \mathrm{Pt}^{2+}, \mathrm{Cd}^{2+} \mathrm{Co}^{2+}, \mathrm{Ni}^{2+}$, dan $\mathrm{Fe}^{3+}$. Akibatnya ion-ion tersebut menggangu dalam pengukuran secara spektrofotometri atau disebut gangguan matriks.

Efek gangguan matriks dalam analisis kimia adalah menurunkan sensitifitas dan memberikan singal/hasil pengukuran yang berbeda dengan nilai sebenarnya. Akibatnya apabila data tersebut digunakan untuk mengambil kesimpulan dalam sebuah penelitian, maka akan dihasilkan kesimpulan salah [10]

Beberapa metode yang digunakan dalam mengeliminasi gangguan matrik antara lain adalah dengan menambahkan zat penopeng (memecah senyawa kompleks non alanit) [11], ekstraksi pelarut (memisahkan senyawa kompleks non analit) [12], dan teknik adisi standar (mengkondisikan matrik sampel sama dengan standar) [13], [10],[14]. Sejauh penelusuran pustaka yang ditemukan, penelitian eliminasi gangguan matrik pada analisis merkuri dengan sistem TMK secara spekrofotometri belum pernah dilakukan. Oleh sebab itu dalam upanya mewujudkan sebuah metode analisis merkuri dengan biaya relatif murah, sederhana dan validitas tinggi, maka penelitian ini perlu dilakukan.

Sehubungan dengan hal tersebut, "Penambangan Emas Tradisional " yang menggunakan merkuri telah banyak dijumpai di beberapa daerah, misalnya Jawa, Kalimantan, Sulawesi dan Lombok. Untuk kasus di Pulau Lombok, penggunaan merkuri dalam gelondongan emas banyak ditemui di Kabupaten Lombok Tengah, Lombok Tengah dan Mataram. Dari hasil penelitian terdahulu yang dilakukan oleh Istiqo, sekitar $10 \%$ dari penggunaan merkuri tersebut terbuang ke lingkungan (udara, tanah, tanaman/sayuran, biota air tawar, biota laut) dan pada akhirnya manusia [15]. Oleh sebab itu pendeteksian merkuri di daerah-daerah yang diduga tercemar merkuri perlu dilakukan. Hal tersebut akan dapat terwujud bila tersedia metode yang sederhana, murah dan memiliki validitas tinggi.

Tujuan umum penelitian ini adalah tersusunnya metode analisis merkuri $\mathrm{Hg}$ secara spektrofotometri bebas dari gangguan matriks, sehingga menjadi metode dengan biaya relatif murah, sederhana dan memiliki validitas tinggi dan dapat diterapkan dengan baik untuk analisis merkuri dalam sampel lingkungan (air, tanah) dan bahan pangan (ikan, sayuran). Adapun tujuan khusus dari penelitian ini adalah: (1) Menentukan kondisi optimum proses pembentukan senyawa kompleks Hg-Thio Michler's keton: $\lambda_{\max }$, pengaruh $\mathrm{pH}$, dan konsentrasi TMK, (2) Menentukan validasi metode: linieritas, limit deteksi, \% recovery, dan selektivitas, dan (3) Menyeleksi metode eliminasi gangguan matriks: metode zat penopeng, ekstraksi pelarut, dan adisi standar.

\section{METODE PENELITIAN}

\section{Peralatan dan Bahan Kimia}

Peralatan yang digunakan terutama adalah Spektrofotometer Uv-Vis Perkin-Elmer Lamda 45 UvVis., $\mathrm{pH}$ meter, water bath, sentrifugasi, dan peralatan gelas (labu takar, pipet volum, dan lain-lain).

Bahan yang digunakan semuanya berkualitas pa., yaitu $1000 \mathrm{ml}$ larutan stok ion logam: $\mathrm{Hg}(\mathrm{II}), \mathrm{Cu}(\mathrm{II})$, $\mathrm{Ag}(\mathrm{I}), \mathrm{Pt}(\mathrm{II}), \mathrm{Au}(\mathrm{III}), \mathrm{Co}(\mathrm{II}), \mathrm{Ni}(\mathrm{II}), \mathrm{Fe}(\mathrm{II})$ masingmasing $1000 \mathrm{mg} / \mathrm{L}$. Pereaksi Thio Michler's Ketone (TMK)/4,4'-Bis(dimethylamino)thio-benzophenone,

Dietil eter, $\mathrm{NaCl}, \mathrm{H}_{2} \mathrm{SO}_{4}, \mathrm{KMnO}_{4}, \mathrm{HNO}_{3}, \mathrm{NH}_{4} \mathrm{OH}$, EDTA, $\mathrm{HClO}_{4}$, natrium asetat, asam asetat glasial, etanol, dietil eter, dan kertas saring. Penelitian ini dilakukan di Laboratorium Kimia, FKIP Unram dan Lab. Kimia Dasar FMIPA Unram. Prosedur kerja penelitian ini mengacu pada penelitian terdahulu [8], [11], [16],[17], [18]

\section{Prosedur Kerja}

\section{(a) Pembuatan Larutan}

Larutan kerja/siap digunakan sebanyak $500 \mathrm{~mL}$, yaitu: $\mathrm{Hg}(\mathrm{II}), \mathrm{Cu}(\mathrm{II}), \mathrm{Ag}(\mathrm{I}), \mathrm{Pd}(\mathrm{II}), \mathrm{Pt}(\mathrm{II}), \mathrm{Au}(\mathrm{III})$, $\mathrm{Co}(\mathrm{II}), \mathrm{Ni}(\mathrm{II}), \mathrm{Fe}(\mathrm{II}) 10 \mathrm{mg} / \mathrm{L}$, TMK $1 \times 10^{-3} \mathrm{M}(0,0285$ $\%$ w/v), bufer asetat pH $2-\mathrm{pH} 5, \mathrm{H}_{2} \mathrm{SO}_{4} 1 \mathrm{M}, \mathrm{NaCl} 2$ $\mathrm{M}$, EDTA $1 \%, \mathrm{KMnO}_{4} 1 \%$

\section{(b) Prosedur Analisis Umum}

Prosedur analisis ini bermaksud untuk mendapatkan senyawa kompleks terbaik yang ditunjukkan oleh warna yang terbentuk. Proses reaksi pembentukan senyawa kompleks adalah sebagai berikut: ke dalam labu takar $50 \mathrm{ml}$ dimasukan masingmasing: $5 \mathrm{ml}$ larutan $\mathrm{Hg}^{2+}$ (konsentrasi absolut $0.00-$ 2,00 mg/L), buffer asetat ( $\mathrm{pH} 2 \mathrm{~s} / \mathrm{d} \mathrm{pH} 5)$, TMK (0,0001-0,0004 M), dan akua bebas ion $35 \mathrm{~mL}$. Selanjutnya didiamkan dengan waktu 1 s/d 12 menit, sehingga terbentuk senyawa kompleks $\mathrm{Hg}$ TMK berwarna hijau kebiruan. Larutan yang terbentuk segera diukur dengan spektrofotometer pada panjang gelombangn $200-800 \mathrm{~nm}$ sehingga diperoleh spektrum panjang gelombang dan $\lambda_{\max }$

\section{(c) Penentuan Kondisi Optimum Analisis}

Prosedur analisis mengacu pada prosedur analisis umum no. 2.2(1) tetapi formula jumlah pereaksi direduksi sebesar $1 / 5$ kali. Ke dalam tabung 
reaksi $20 \mathrm{ml}$ dimasukan masing - masing $1 \mathrm{~mL}$ : larutan $\mathrm{Hg}^{2+}$ 0,8 mg/L, buffer $\mathrm{pH} \mathrm{3,} \mathrm{TMK} \mathrm{0,002} \mathrm{M,} 7$ $\mathrm{ml}$ akua bebas ion, dan waktu tunggu 4 menit. Penentuan panjang gelombang dilakukan dengan cara mengukur absorban pada panjang gelombang 200-700 $\mathrm{nm}$. Penentuan $\mathrm{pH}$ optimum dilakukan dengan cara

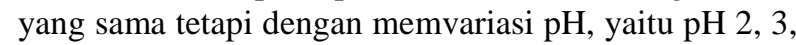
4 , dan 5, selanjutnya absorban diukur pada $\lambda_{\text {max }}$. Penentuan konsentrasi TMK optimum dilakukan dengan cara yang sama, tetapi menggunakan variasi konsentrasi TMK, yaitu 0,001 M, 0,002 M, 0,003 M, dan 0,004 M. Selanjutnya penentuan waktu kestabilan kompleks juga dilakukan dalam kondisi yang sama tetapi, menggunakan waktu tunggu bervariasi, yaitu 1 , $2,4,8,10,12$ menit, kemudian absorban diukur pada $\lambda_{\max }$

\section{(d) Penentuan Validitas Metode}

Prosedur analisis mengacu pada prosedur analisis umum no. 2.2(3). Untuk limit deteksi digunakan variasi konsentrasi $\mathrm{Hg}$ (II) $0,0 \mathrm{~s} / \mathrm{d} 2,0 \mathrm{mg} / \mathrm{L}$ dan dilanjutkan dengan pengukuran 10 blanko. Akurasi ditentukan dengan cara mengukur 5 sampel yang telah diketahui konsentrasinya dengan tepat, yaitu $\mathrm{Hg}$ (II) 0,1 $\mathrm{mg} / \mathrm{L}$ dan $0,2 \mathrm{mg} / \mathrm{L}$. Selektivitas ditentukan dengan cara menambahkan ion-ion pengganggu masing-masing $1 \mathrm{ml}$ ion: $\mathrm{Au}^{3+}, \mathrm{Ag}^{+}, \mathrm{Cu}^{2+}, \mathrm{Pd}^{2+}, \mathrm{Co}^{2+} \mathrm{Fe}^{3+}$, konsentrasi masing-masing seluruhnya: 2 dan $20 \mathrm{mg} / \mathrm{L}$ (2 kali dan 10 kali). Selanjutnya absorban diukur pada $\lambda_{\max }$

\section{(e) Metode Eliminasi Gangguan Matriks Secara Ekstraksi Pelarut}

Prosedur analisis mengacu pada cara 2.2(3) pada kondisi optimum, tetapi mengandung ion $\mathrm{Au}^{3+}, \mathrm{Ag}^{+}$, $\mathrm{Cu}^{2+}, \mathrm{Pd}^{2+}, \mathrm{Co}^{2+} \mathrm{Fe}^{3+}$ dengan konsentrasi masingmasing $20 \mathrm{mg} / \mathrm{L}$ (20 kali lebih tinggi dari $\mathrm{Hg}^{2+}$ ). Prosedur praktis ekstraksi pelarut dilakukan dengan cara ke dalam tabung reaksi $20 \mathrm{ml}$ dimasukan masingmasing: $1 \mathrm{ml}$ larutan $\mathrm{Hg}$ (II) $10 \mathrm{mg} / \mathrm{L}$ (1 mg/L), $1 \mathrm{ml}$ buffer asetat $\mathrm{pH} 3,1 \mathrm{ml}$ TMK 0,002 M, $1 \mathrm{ml}$ larutan ion pengganggu $200 \mathrm{mg} / \mathrm{L}(20 \mathrm{mg} / \mathrm{L})$ dan $6 \mathrm{ml}$ akua bebas ion. Selanjutnya ditambahkan $3 \mathrm{ml}$ dietil eter untuk dilakukan ekstraksi selama 30 - 60 detik. Absorban diukur pada $\lambda \max$.

\section{(f) Metode Eliminasi Gangguan Matriks dengan Zat Penopang}

Prosedur praktis mengacu pada cara 2.2(3) sebagai berikut ke dalam tabung reaksi $20 \mathrm{ml}$ dimasukan masing - masing: $1 \mathrm{ml}$ larutan $\mathrm{Hg}$ (II) 10 $\mathrm{mg} / \mathrm{L}(1 \mathrm{mg} / \mathrm{L}), 1 \mathrm{ml}$ buffer asetat $\mathrm{pH} 3,1 \mathrm{ml} \mathrm{TMK}$ 0,002 M, $1 \mathrm{ml}$ larutan ion pengganggu $200 \mathrm{mg} / \mathrm{L} \mathrm{(20}$ $\mathrm{mg} / \mathrm{L}$ ) dan $6 \mathrm{ml}$ akua bebas ion. Setelah diaduk selama $30-60$ detik, absorban diukur pada $\lambda$ max.

\section{(g) Metode Adisi Standar/Penambahan Larutan Standar}

Studi metode adisi standar dalam penelitian digunakan 2 jenis matriks sampel, yaitu sampel buatan dan matriks sampel asli berupa air sungai dan sedimen Untuk penggunaan sampel buatan dilakukan dengan cara dibuat larutan $\mathrm{Hg}^{2+} 0,05 \mathrm{mg} / \mathrm{L}$ yang mengandung ion: $\mathrm{Au}^{3+}, \mathrm{Ag}^{+}, \mathrm{Cu}^{2+}, \mathrm{Pd}^{2+}, \mathrm{Co}^{2+} \mathrm{Fe}^{3+} 20 \mathrm{mg} / \mathrm{L}$. Prosedur yang dilakukan adalah sebagai berikut: ke dalam 5 tabung reaksi $20 \mathrm{ml}$ masing - masing dimasukkan: $1 \mathrm{ml}$ ion pengganggu $200 \mathrm{mg} / \mathrm{L}, 1 \mathrm{ml}$ TMK 0,002 M, $1 \mathrm{ml}$ bufer asetat $\mathrm{pH} 3,6 \mathrm{ml}$ larutan sampel sintesis yang mengandung $\mathrm{Hg}(\mathrm{II}) \quad 0,05 \mathrm{mg} / \mathrm{L}$ dan $1 \mathrm{ml}$ larutan ion pengganggu secara komulatif $200 \mathrm{mg} / \mathrm{L}$, dan $1 \mathrm{ml}$ larutan standar $\mathrm{Hg}(\mathrm{II})$ dengan konsentrasi masingmasing 0,$05 ; 0,10 ; 0,15$; dan 0,20 mg/L. Absorban diukur pada $\lambda$ max. Dengan cara yang sama percobaan ini diulang sebanyak 5 kali dengan konsentrasi yang sama, yaitu $0,05 \mathrm{mg} / \mathrm{L}$. Untuk sampel nyata tidak ditambahkan ion pengganggu.

\section{Analisis Data}

Seluruh data hasil penelitian dihitung melalui komputer program Excell. Data yang diperoleh selanjutnya disajikan dalam bentuk spektrum, kurva atau tabel

\section{HASIL DAN PEMBAHASAN \\ 3.1. Kondisi Optimum Analisis}

Dalam analisis kation (ion logam) secara spektrofotometri, tahap awal adalah penentuan kondisi optimum. Kondisi tersebut terutama yang terkait dengan reaksi spesifik antara ion logam dengan pereaksi spesifik untuk membentuk senyawa kompleks dengan stabilitas optimum.

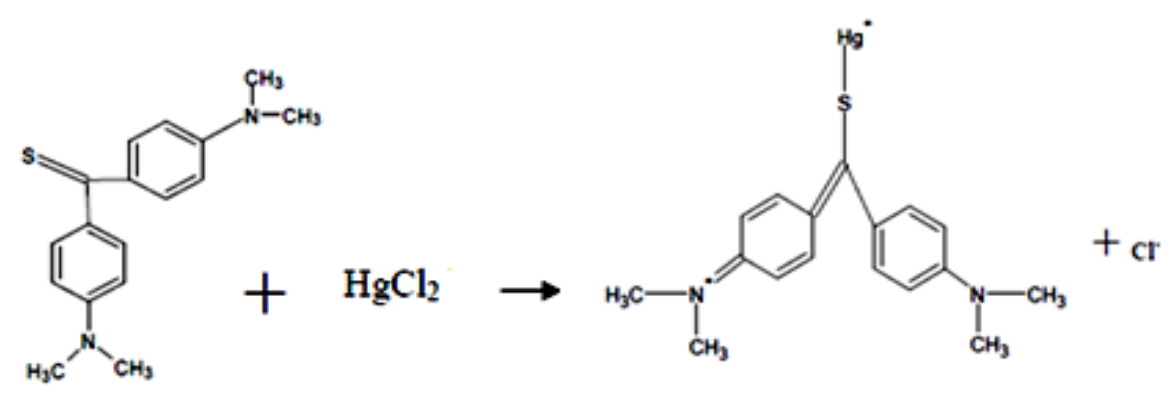

Gambar 1. Reaksi pembentukan senyawa kompleks Hg-TMK 
Pembentukan senyawa kompleks dengan ligan Thio Michler's Ketone TMK (4,4'Bis(dimethylamino)thio-benzophenone) ditentukan oleh beberapa faktor, yaitu $\mathrm{pH}$, konsentrasi TMK, dan waktu reaksi. Dari aspek kimia analitik, senyawa kompleks Hg-TMK yang terbentuk akan memberikan warna dan bersifat kondisional (tergantung kondisi) (Gambar1)

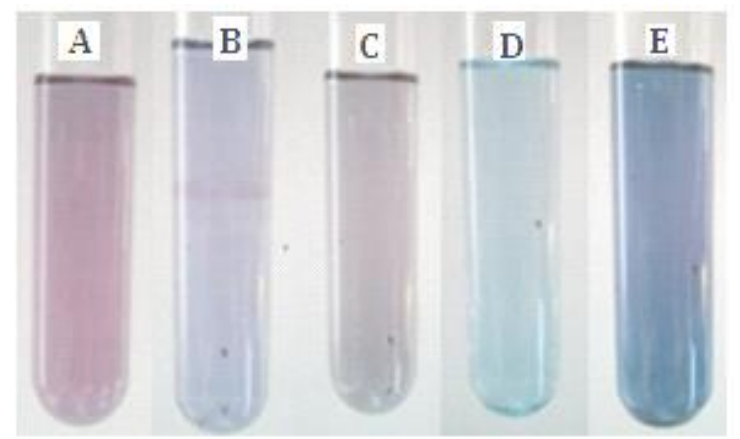

Gambar 1. Berbagai produk senyawa kompleks $\mathrm{Hg}$ TMK yang terbentuk: A) kelebihan pereaksi, (B) kelebihan sedikit pereaksi, (C) pH terlalu tinggi, (D) kondisi yang tepat, (E) kondisi adanya ion $\mathrm{Ag}, \mathrm{Cu}$, $\mathrm{Au}, \mathrm{Co}, \mathrm{Ni}, \mathrm{Fe} 1 \mathrm{ppm}$

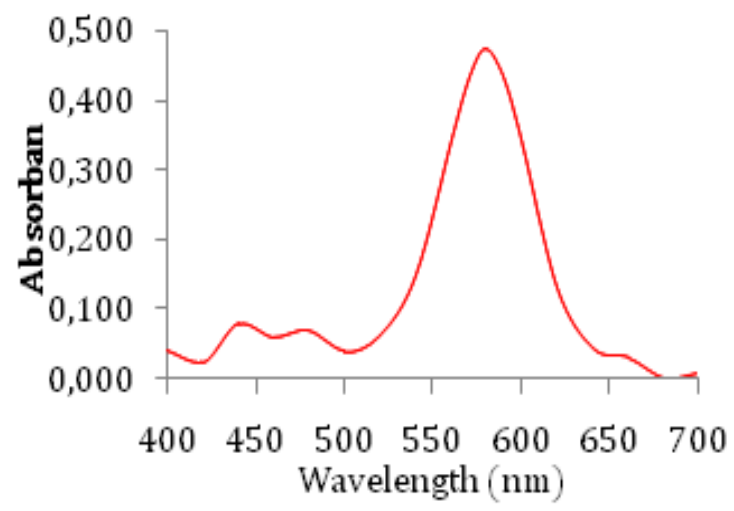

Gambar 2. Spektrum senyawa kompleks Hg-TMK, $\lambda$ max sekitar $574 \mathrm{~nm}$

Berdasarkan gambar 1 dapat ditunjukkan bahwa senyawa kompleks D merupakan senyawa kompleks berwarna hijau kebiruan dari $\mathrm{Hg}$-TMK. Dari aspek kimia analitik, maka kondisi tersebut yang paling sesuai, karena warna tersebut merupakan warna dari senyawa kompleks Hg-TMK. Untuk membuktikan kebenaran senyawa tersebut, maka dapat ditunjukkan oleh spektrum di daerah sinar tampak sebagaimana gambar 2.

Berdasarkan gambar 2 dapat ditunjukan bahwa senyawa kompleks Hg-TMK menunjukan serapan maksimum pada panjang gelombang 574 nm. Hal ini memiliki arti dari aspek analisis kimia bahwa deteksi merkuri yang didasarkan pada pembentukan senyawa kompleks Hg-TMK sebaiknya dilakukan pengukuran pada $\lambda \max 574 \mathrm{~nm}$.

(1) Pengaruh pH Terhadap Absorban Senyawa Kompleks

Dengan meninjau struktur senyawa kompleks Hg-TMK, maka pH akan berpengaruh pada stabilitas gugus $=\mathrm{N}\left(\mathrm{CH}_{3}\right) \mathrm{X}$ dimana dalam $\mathrm{pH}$ rendah, senyawa kompleks cenderung lebih stabil dalam bentuk tidak bermuatan. Dalam penelitian ini pengaruh $\mathrm{pH}$ terhadap proses pembentukan kompleks dilakukan pada $\mathrm{pH} 2 ; 3 ; 4$ dan 5 . Pengaruh $\mathrm{pH}$ terhadap struktur senyawa kompleks $\mathrm{Hg}$-TMK juga dapat ditunjukkan oleh perubahan spektrum pada berbagai $\mathrm{pH}$ sebagimana terlihat pada gambar 3 .

Berdasarkan spektrum pada gambar 3 menunjukkan bahwa serapan yang cukup tinggi dari senyawa kompleks Hg-TMK terjadi pada pH 2 dan 3. Hal ini dapat dijelaskan berdasarkan struktur senyawa kompleks tersebut. Senyawa kompleks $\mathrm{Hg}$-TMK terjadi akibat ikatan antara ligan basa dengan ion $\mathrm{Hg}$ (II) dimana ligan tersebut berada dalam bentuk ion. Oleh sebab itu ligan lebih stabil dalam kondisi asam. Sebaliknya apabila dalam kondisi basa, maka ligan tersebut akan berada dalam bentuk molekul bebas. Oleh sebab itu ikatan ligan-logam lemah, sehingga memberikan serapan yang relatif lebih rendah dibandingkan dengan kondisi asam. Dalam kondisi basa juga muncul serapan pada daerah panjang gelombang sekitar $400 \mathrm{~nm}$. Hal ini menunjukkan adanya molekul bebas dari ligan TMK.

\section{(2) Pengaruh Konsentrasi TMK Terhadap} Absorban

Pengaruh konsentrasi TMK atau 4,4'Bis(dimethylamino)thio-benzophenone terhadap serapan maksimum terkait dengan struktur senyawa kompleks yang terbentuk. Dalam penelitian ini konsentrasi TMK yang digunakan adalah antara 0,0001M s/d 0,0004 M, namun absorban maksimum ditemukan pada konsentrasi 0,0002 M. Dari aspek analisis kimia menunjukkan bahwa serapan maksimum tergantung pada perbandingan konsentrasi $\mathrm{Hg}$ dan TMK. Sebagaimana dilaporkan oleh peneliti terdahulu pembentukan senyawa kompleks antara logam dan ligan akan mengikuti hukum stoikhiometri dengan perbandingan mol tertentu [1], [6], [8]

\section{(3) Pengaruh Waktu Terhadap Stabilitas Kompleks}

Waktu tunggu (waktu kestabilan) dalam analisis secara spektrofotometri yang melalui pembentukan senyawa kompleks merupakan hal yang perlu diperhatikan, karena akan berpengaruh pada hasil analisis. Dari hasi pengukuran 


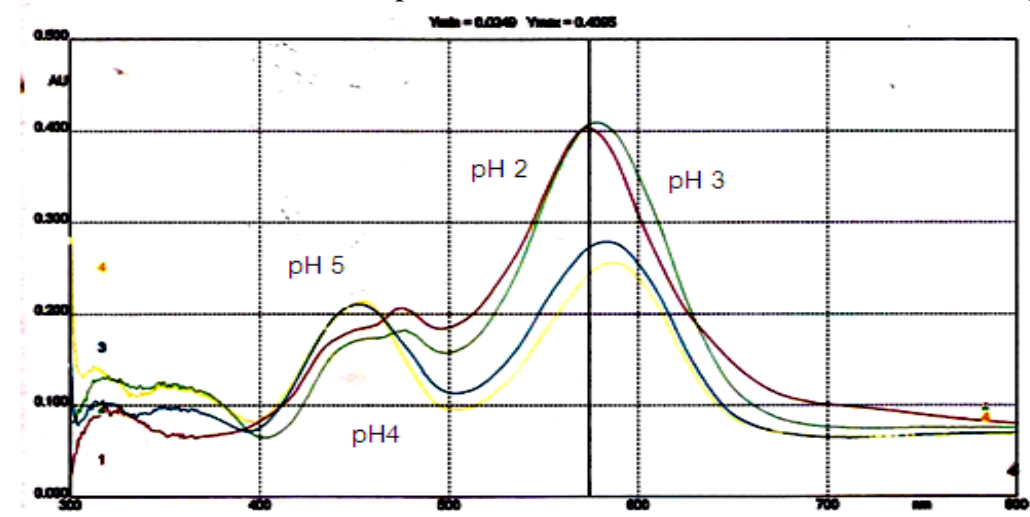

Gambar 3. Spektrum senyawa kompleleks Hg-TMK pada berbagai pH pada kondisi: $\mathrm{Hg}(\mathrm{II})=0,8 \mathrm{ppm}$, [TMK]

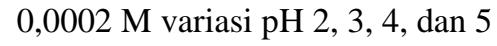

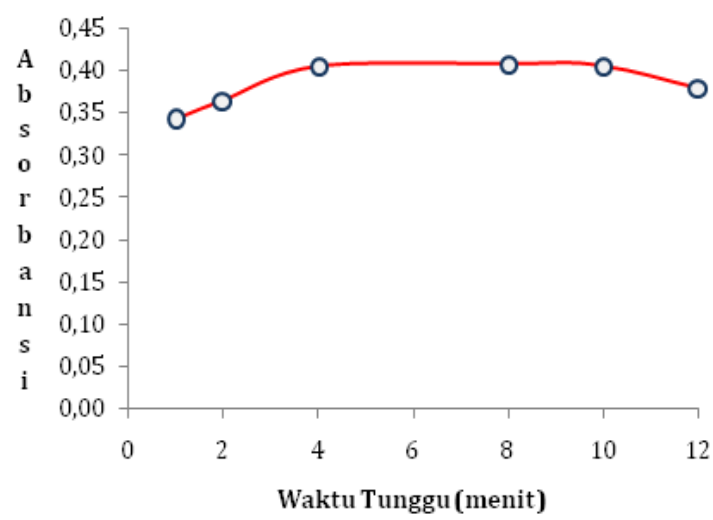

Gambar 4. Kurva hubungan antara absorban dan waktu kestabilan

Dari aspek kimia analitik, maka untuk analisis kimia sebaiknya menggunakan waktu tunggu antara 4 sampai dengan 10 menit. Sebagaimana dilaporkan oleh peneliti terdahulu juga menunjukkan bahwa stabilitas senyawa kompleks ditentukan oleh waktu. Oleh sebab itu untuk keperluan analisis kimia penetapan waktu kestabilan sangat diperlukan [6], [8], [15], [16]

\subsection{Validitas Metode Analisis Merkuri (1) Linieritas Kurva Standar dan Limit Deteksi}

Linieritas kurva standar dimaksudkan untuk mengetahui sejauh mana jangkauan alat spektrofotometer dapat mendeteksi merkuri-TMK. Oleh karena sinyal yang ditunjukkan alat spektrofotometer adalah nilai absorban A sedangkan tujuan akhir adalah menentukan konsentrasi $\mathrm{C}$, maka kurva linieritas ditunjukkan dengan kurva absorban terhadap konsentrasi $\mathrm{C}$ sebagaimana tercantum dalam gambar 5

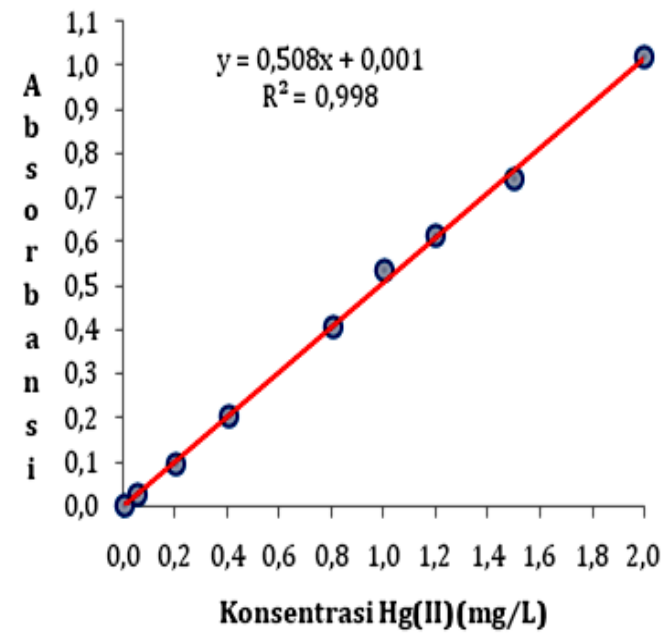

Gambar 5. Kurva linieritas hubungan absorban dan konsentrasi $\mathrm{Hg}(\mathrm{II})$

Berdasarkan kurva linieritas pada gambar 5 dapat ditunjukkan bahwa kurva standar bersifat linier dengan $\mathrm{R}^{2}=0,998$ pada rentang konsentrasi 0,05-2,0 $\mathrm{mg} / \mathrm{L}$. Selanjutnya untuk keperluan perhitungan limit deteksi, maka telah dilakukan pengukuran 10 kali blanko dengan nilai rata-rata absorban sebesar 0,002 dan standar deviasi sebesar 0,001.

Dengan mengacu pada penelitian terdahulu [9], maka berdasarkan rumus $\mathrm{C}_{\mathrm{L}}=3 \mathrm{~S}_{\mathrm{B}} / \mathrm{s}$ diperoleh limit deteksi sebesar $0,0080 \mathrm{mg} / \mathrm{L}$ atau $0,0080 \mathrm{ppm}$ atau 0,008 $\mu \mathrm{g} / \mathrm{mL}$.

\section{(2) Akurasi Metode Analisis}

Akurasi dihitung berdasarkan nilai \% recovery dari sampel buatan yang telah diketahui konsentrasinya dengan pasti. Berdasarkan hasil perhitungan menunjukkan bahwa \% recovery baik pada konsentrasi $\mathrm{Hg}$ (II) $0,1 \mathrm{mg} / \mathrm{L}$ maupun $0,2 \mathrm{mg} / \mathrm{L}$ diperoleh antara 98\% s/d 102\%. Dari hasil penelusuran literatur juga menunjukkan bahwa 
sebagian besar nilai \% recovery metode analisis sekitar $98-105 \%$ [1], [6], [8]

\section{(3) Selektivitas Metode Analisis}

Selektivitas metode analisis merupakan parameter analisis yang terkait dengan kemampuan alat spektrofotometer untuk mengukur analit yang dalam hal ini senyawa kompleks Hg-TMK dengan tanpa terganggu ion lain. Dalam penelitian ini ditemukan bahwa ion-ion $\mathrm{Au}(\mathrm{III}), \mathrm{Cu}(\mathrm{II}), \mathrm{Ag}(\mathrm{I}), \mathrm{Pd}(\mathrm{II})$ memberikan gangguan kecuali $\mathrm{Co}(\mathrm{II})$, dan $\mathrm{Fe}(\mathrm{II})$. Dari hasil pengukuran menunjuk-kan bahwa ion-ion $\mathrm{Au}(\mathrm{III}), \mathrm{Ag}(\mathrm{I}), \mathrm{Cu}(\mathrm{II})$, dan $\mathrm{Pd}(\mathrm{II})$ mengganggu baik pada konsentrasi 2 ppm maupun 20 ppm.

\subsection{Seleksi Metode Eliminasi Gangguan Matriks: (1) Metode Ekstraksi Pelarut}

Ekstraksi pelarut merupakan teknik pemisahan suatu analit (senyawa kompleks) berdasarkan perbedaan kekuatan distribusi antara 2 fasa, yaitu fasa air (polar) dan fasa organik (non polar) [12].

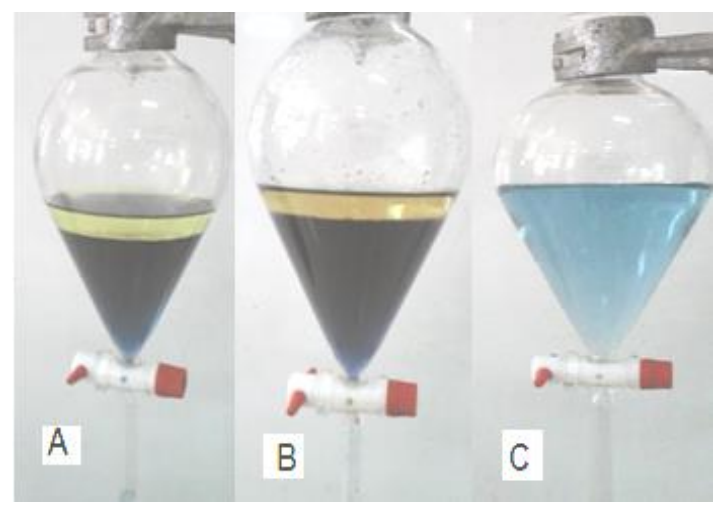

Gambar 6. Proses ekstraksi senyawa kompleks logam-TMK dengan pelarut organik dietil eter: A dan B merupakan proses ekstraksi, (C) hasil ekstraksi

Dalam penelitian ini pelarut organik yang digunakan adalah dietil eter yang merupakan pelarut organik non polar. Hasil ekstraksi ditunjukkan pada gambar 6 . Berdasarkan gambar tersebut dapat ditunjukan bahwa larutan A dan B sebelum proses ekstraksi cenderung berwarna biru kemerahan. Hal ini disebabkan terjadi campuran senyawa kompleks Au-TMK, Ag-TMK, $\mathrm{Cu}-\mathrm{TMK}$, dan logam pengganggu lainnya.

Namun demikian setelah proses ekstraksi larutan fasa air berubah menjadi hijau kebiruan. Hal ini menunjukkan bahwa senyawa kopmpleks Hg-TMK tetap berada dalam fase air, sedangkan kompleks logam-TMK yang lain terdistribusi dalam fase organik.

\section{(2) Metode Penambahan Zat Penopeng (Masking Agent)}

Penambahan masking agent atau zat penopeng ke dalam larutan analit yang mengandung ion pengganggu bertujuan untuk mengikat ion-ion pengganggu dengan cara menambahkan ligan tertentu dengan harapan akan membentuk senyawa kompleks yang lebih stabil dibandingkan dengan ligan TMK. Zat penopeng yang digunakan dalam penelitian ini adalah: EDTA, Na-sitrat, dan KNa Tartrat, serta $\mathrm{NaCl}$.

Secara umum penggunaan zat pebnopang EDTA tidak efektif karena ligan tersebut membentuk kompleks dengan analit $\mathrm{Hg}(\mathrm{II})$. Hal ini dapat dilihat dari nilai - $\log \mathrm{Kf}$, L-EDTA, yaitu: Hg-EDTA sebesar 21,8; Ag-EDTA 7,32; Cu-EDTA 18,79; Co-EDTA 16,21; Pd-EDTA 25,6, dan Fe-EDTA 25,10. Akibat besarnya nilai $\mathrm{Kf} \mathrm{Hg-EDTA,} \mathrm{maka} \mathrm{ion} \mathrm{Hg}$ akan lebih terikat pada ligan EDTA. Hal yang sama juga pada jenis ligan yang lain.

\section{(3) Metode Adisi Standar}

Metode adisi standar adalah cara membuat kondisi larutan standar yang sama dengan larutan sampel, dengan cara menambahkan sejumlah konsentrasi/volume larutan standar kedalam sampel [14]. Dengan adanya matrik sampel yang sama dengan matrik standar, maka gangguan-gangguan matrik dapat dieliminasi.

Dalam penelitian ini teknik adisi standar diterapkan pada sampel buatan, sampel air sungai dan sampel sedimen.

Berdasarkan kurva adisi standar tersebut di atas diperoleh untuk sampel buatan ditemukan titik potong dengan sumbu $X$ adalah di titik $-0,053 \mathrm{mg} / \mathrm{L}$, sedangkan untuk sampel air sungai diperoleh pada titik -0,034 mg/L. Untuk sampel sedimen diperoleh nilai titik potong dengan sumbu $X$ sebesar $-0,425$ $\mathrm{mg} / \mathrm{L}$ (Gambar 7). Hubungan antara nilai $X$ pada saat $\mathrm{Y}=0$ dinyatakan dalam persamaan:[13],[10],[14], [19]

$$
x=\frac{k C x V s / \text { Vas }}{k C s t / \text { Vas }}=-C x V s t / C s t
$$

Oleh sebab itu dapat dihitung bahwa konsentrasi $\mathrm{Hg}$ (II) dalam sampel buatan sebesar $0,053 \mathrm{mg} / \mathrm{L}$ dan konsentrasi $\mathrm{Hg}$ (II) dalam sampel air sungai sebesar $0,034 \mathrm{mg} / \mathrm{L}$. 


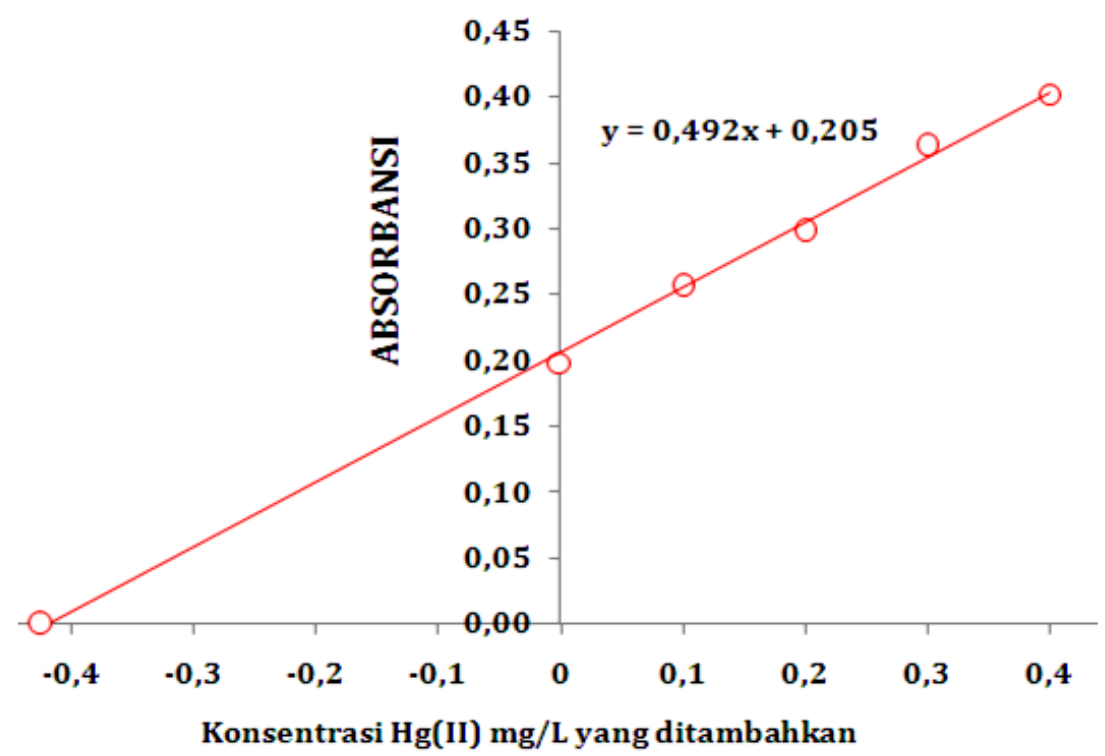

Gambar 7. Kurva adisi standar pada analisis $\mathrm{Hg}$ (II) dalam sedimen

Berdasarkan kurva adisi standar pada gambar 6, maka dapat diperoleh bahwa titik potong dengan sumbu $\mathrm{X}$ terjadi pada nilai - 0,425 $\mathrm{mg} / \mathrm{L}$ sehingga konsentrasi $\mathrm{Hg}$ (II) dalam sampel sedimen yang terukur sebesar $0,425 \mathrm{mg} / \mathrm{L}$. Namun demikian karena terjadi faktor pengenceran sebesar 10 kali, maka konsentrasi $\mathrm{Hg}$ (II) dalam sedimen sebesar 4,25 mg/kg berat kering udara. Selanjutnya untuk membuktikan kebenaran metode adisi standar, maka pengukuran sebanyak 5 sampel disajikan pada tabel 1 .

Tabel 1. Konsentrasi $\mathrm{Hg}(\mathrm{II})$ hasil pengukuran dengan metode adisi standar

\begin{tabular}{lc}
\hline \multicolumn{1}{c}{ Sampel } & Konsentrasi $\mathrm{Hg}(\mathrm{II})$ \\
\hline Sampel buatan $0,05 \mathrm{mg} / \mathrm{L}$ & $(0,053 \pm 0,001) \mathrm{mg} / \mathrm{L}$ \\
Sampel air sungai & $(0,034 \pm 0,004) \mathrm{mg} / \mathrm{L}$ \\
Sampel sedimen & $(4,172 \pm 0,050) \mathrm{mg} / \mathrm{kg}$ \\
\hline
\end{tabular}

Berdasarkan data pada tabel 1' menunjukan bahwa dengan taraf kepercayaan 5\% hasil pengukuran dengan metode adisi standar menunjukan nilai yang hampir sama. Oleh sebab itu metode adisi standar dapat digunakan untuk pengukuran sampel yang mengandung matriks pengganggu.

\section{KESIMPULAN}

Kesimpulan yang diperoleh dari penelitian ini adalah sebagai berikut: Metode analisis merkuri melalui pembentukan senyawa kompleks dengan 4,4'Bis(dimethyl-amino)thio-benzophenone TMK secara spektrofotometer UV-Vis memiliki kondisi optimum: $\lambda \max 574$ nm; pH 3; konsentrasi TMK 0,0002 M, dan waktu tunggu selama 4-10 menit. Formula pereaksi $\mathrm{Hg}(\mathrm{II})$, bufer $\mathrm{pH} 3$, TMK $0,002 \mathrm{M}, \mathrm{H}_{2} \mathrm{O}$ bebas ion dalam perbandingan volume adalah: 1:1:1:7. Metode analisis merkuri melalui pembentukan senyawa kompleks dengan 4,4'-Bis(dimethylamino)thiobenzophenone TMK, telah memenuhi validitas sebagai metode analisis, yaitu: linieritas $0,05-2,0$ $\mathrm{mg} / \mathrm{L}$, limit deteksi $0,008 \mathrm{mg} / \mathrm{L}$, dan \%recovery antara 98\% - 102\%. Gangguan matriks akibat adanya ionion $\mathrm{Au}(\mathrm{III}), \mathrm{Ag}(\mathrm{I}), \mathrm{Pd}(\mathrm{II}), \mathrm{Cu}(\mathrm{II}), \mathrm{Co}(\mathrm{II})$, dan $\mathrm{Fe}(\mathrm{II})$ dapat dieliminasi dengan metode ekstraksi pelarut dan adisi standar.

\section{DAFTAR PUSTAKA}

[1] Friedmann, A.S., H. Chen, dan B.R. Zirkin, 1998. Accumulation of dietary methyl mercury in the testes of the adult Brown Norway rat: Impaired testicular and epididymal function. Environ. Toxicol. Chem., 17: 867-871.

[2] Ramalhosa, E., S.R. Segade, dan A. Duarte. 2011. Monomethylmercury behaviour in sediments collected from a mercury-contaminated lagoon. Intern. J. Environ. Anal. Chem. Vol. 91, No. 1: 49-61

[3] Petruccioli, L. dan P. Turillazzi, 1991. Effects of methyl mercury on acetylcholinesterase and serum cholinesterase Activity in monkeys, Macaca fascicularis. Bull. Environ. Contam. Toxicol., 46:769-773.

[4] WHO. 1990. Methyl mercury. Environmental Health Criteria, World Health Organization, Geneva, 101: 5-76

[5] Clarkson, T.W., M.D. Laszlo Magos dan G.J. Myers. 2003. The toxicology of mercury current exposures and clinical manifestations. Eng J. Med.349:1731-1737. 
[6] Fu, D. dan D. Yuan. 2007. Spectrophotometric determination of trace copper in water samples with thio michlers ketone. Spectrochimica Acta Part A: Molecular and Biomolecular Spectroscopy. Volume 66, Issue 2: 434-437

[7] Gehauf, B. dan J. Goldenson. 1950. 4,4' Bis(dimethylamino)thiobenzophenone as reagent for mercury and certain other metals. Anal. Chem., 22 (3): 498-499

[8] Niazi, A. A. Aziz dan M. Ramezani. 2008. Simultaneous spectrophotometric determination of mercury and palladium with Thio-Michler's Ketone using partial least squares. Spectrochimica Acta Part A: Molecular and Biomolecular Spectroscopy, Volume 71, Issue 3:1172-1177

[9] Sukib dan Loka. 2013. Metode Cepat Analisis Merkuri Hg Secara Cloud Point Extraction Dalam Sistem Thio Michler's Ketone-Triton $\mathrm{X}_{114}$ Secara Spektrofotometri. Laporan Penelitian Lemlit Unram

[10] Kang, J., L.A. Hick, dan W.E. Price. 2007. Using calibration approaches to compensate for remaining matrix effects in quantitative liquid chromatography electrospray ionization multistage mass spectrometric analysis of phytoestrogens in aqueous environmental samples. Rapid Communications in Mass Spectrometry, 21(24): 4065-4072

[11] Li, H.B., F. Chen, dan X.R. Xu. 2000. A Highly sensitive spectrophotometric method with solidphase extraction for determination of methylmercury in human hair. Journal of Analytical Toxicology, Vol. 24, November: $704-$ 707.

[12] Max Roundhill1, D., I.B. Solangi, S. Memon, M. I. Bhanger dan M. Yilmaz. 2009. The liquid- liquid extraction of toxic metals $(\mathrm{Cd}, \mathrm{Hg}$ and $\mathrm{Pb})$ by calixarenes. J. Anal. Environ. Chem. Vol. 10, No. 1 \& $2: 1-13$

[13] Bader, M. 1980. A systematic approach to standard addition methods in instrumental analysis. Journal of Chemical Education 57:703-706.

[14] Taylor, B.W., C. Keep, R.O. Hall, B.J. Koch, dan L.M. Tronstad. 2007. Improving the fluorometric ammonium method: matrix effects, background fluorescence, and standard additions. J. N. Am. Benthol. Soc., , 26(2):167-177

[15] Istiqo, N., Muti'ah, Sukib. 2011. Studi Analisis Logam Merkuri Dalam Air dan Sedimen Limbah Tambang Emas Rakyat di Desa Pengenjek Kecamatan Jonggat Lombok. Laporan Penelitian Progdi. Kimia FMIPA Unram

[16] Cheng, K.L dan L. Goydish. 1966. 4,4'Bis(dimethylamino)thiobenzophenone as a sensitive reagent for mercury and palladium. Microchemical Journal, Volume 10, Issues 1- 4 : $158-170$

[17] Cheng, K.L. 1967. Spectrophotometric determination of microgram and submicrogram amounts of silver with thio-Michlers ketone. Microchimica Acta, Vol. 55: No. 5: 820 - 827

[18] Meera, R., T. Francis dan M. L. P. Reddy. 2001. Studies on the liquid-liquid extraction of mercury(II) from acidic chloride solutions using Cyanex 923, Hydrometallurgy, 61(2),97-103.

[19] Bruce, G. R., dan P.S. Gill.1999. Estimates of precision in a standard additions analysis. Journal of Chemical Education76:805-807. 